\title{
Open Innovation in the Visegrád Four Countries: A Literature Review
}

DOI 10.18267/pr.2021.krn.4816.4

\author{
Tatiana Hlušková \\ ORCID iD: not available \\ tatiana.hluskova@euba.sk \\ ${ }^{1}$ University of Economics in Bratislava, Faculty of Commerce, Department of \\ International Business \\ Bratislava, Slovakia
}

\begin{abstract}
The aim of the paper is to analyze and systematize existing body of literature concerning the concept of Open Innovation in the Visegrád Four countries. The extent of research papers and articles focusing specifically on the Open Innovation in the V4 countries is rather limited. They tend to be included in the larger research samples of the EU member states which limits the possibility of their comparison with other European or non-European countries. 11 sub-topics of the Open Innovation were identified in 36 studies which were analyzed for the purpose of this paper. Nevertheless, it is rather difficult to establish differences or similiarities of the Open Innovation approach among all of the V4 countries because overlapping of the research topics in different studies is not very significant. Further research might be therefore focused on the comparison of different Open Innovation sub-topics across all four Visegrád countries.
\end{abstract}

Keywords: Open Innovation, Visegrád Four, literature review

JEL Classification codes: 036,032

\section{INTRODUCTION}

Open innovation (OI) is a theoretical concept which was first characterised by Chesbrough (2003). In today's highly competitive markets and rapidly changing environment, this idea did not lose any of its relevance. The idea of cooperation with internal and external environment provides not only for more sources of innovative ideas but also for risk-sharing with partner entities and more possibilities to gain finance needed to develop and commercialise these ideas.

The countries of the Visegrád Group are similar in many aspects of their economic development and structure. After the fall of the Iron Curtain their common goals were to make the transition from the centrally-planned to market economies and to join the European Union. Both of these goals were achieved successfully. All four states have become large exporters and have (with a slight exception of Poland) a high degree of openness of economy. However, their export success is dependent on foreign investment to a large extent. The transition to economies led by innovations with high value-added is not without problems.

The Open Innovation concept might be therefore useful for these countries in terms of access to new promising innovative ideas as well as external finance sources. Given that the Visegrád Group states are large recipients of the EU funds this benefit of Open Innovation might be of high importance. 
However, the V4 cannot be considered as a homogeneous group of countries because there are also differences in respective aspects of their business environment. These states are often competing for the same foreign investment and as the importance of competitive advantage based on innovation grows even more, the ability of companies to cooperate and source innovative ideas from different environments will be key for their future success.

The paper consists of literature review, methodology section explaining the method and the construction of the research sample. Results and discussion section summarizes the main topics and findings of the studies in the research sample. Conclusion part specifies the purpose and usefulness of the findings, limitations of the methodology and further research proposals.

\section{LITERATURE REVIEW}

Open Innovation has become a popular topic of the management research since the important work of Chesbrough was first published in 2003. Chesbrough (2003) defines Open Innovation in the following context: "valuable ideas can come from inside or outside the company and can go to market from inside or outside the company as well".

However, there are many subcategories connected to Open Innovation which are examined by other authors. Several studies have dealt with the relation between Open Innovation and company culture. According to Alassaf et al. (2020), openness of the company culture increases the probability of adoption of the OI concept (including both outside-in and insideout types). Employees' knowledge and rewards for OI activities also have positive impact. Success in development of a functioning OI model depends on company goals, capabilities and maturity (Podmetina et al., 2018). Entrepreneurial culture focused on the flexibility and experimenting creates space for radical innovations (Knošková, 2015). Mazur and Zaborek (2016) innovative culture had positive effect on the scope of OI sources of the SMEs in Poland. The relation between innovative culture and percentage of sales from new and modified products as a metric of innovativeness was not proven.

One of the most important issues related to the Open Innovation (and innovation in general) are intellectual property rights. Battisti et al. (2015) state that leading innovators tend to internationalize their activities and use intellectual property rights to protect their innovations. Dodourova and Bevis (2014) think that network leadership is crucial for OI as well protection of intellectual property rights and support infrastructure.

Radical innovation is present in the companies with specific features. Radical innovators are open to explore new ideas in the external environment and these companies build external and internal networks and link their innovation projects to company strategy. Their entrepreneurial culture is focused on the flexibility, experimenting and creating space for radical innovations. (Knošková, 2015). According to Greco et al. (2016), larger companies have better chances to develop radical innovations. Radical innovation is present mainly in knowledge-intensive R\&D sectors (Battisti et al., 2015).

Some authors also focused their research on a specific kind of innovation - eco-innovation. The open-eco-innovation led to new and green products but the communication barriers decelerated the implementation and solution process (Civelek et al., 2020). Positive effect of inbound OI practices on eco-innovative performance was confirmed in the study by Leitão et al. (2020). Eco-innovation activities focused at new products and production processes contributed to the higher R\&D intensity in the Czech SMEs (Kmecová - Vokoun, 2020).

Another issue examined in the papers was the usage of the OI concept in the different stages of the value or innovation chain. Dodourova and Bevis (2014) have found out that mature segments of the automotive industry display lower propensity to OI as compared to emerging segments such as design and development of electrical vehicles. According to Dries et al. 
(2013; 2014), OI in the Hungarian wine sector occurred in the idea generation phase in $63 \%$ of the surveyed companies. in the development and commercialization phases the share of OI decreased to $55 \%$ and $43 \%$, respectively. OI approach is present in high-tech but also nonhigh-tech industries as well (Dziurski - Sopińska, 2020).

Three articles have investigated OI in the manufacturing sector. Lesáková et al. (2018) state that Slovak SMEs in the sector "Manufacture of machinery and equipment not elsewhere classified" consider cooperation with external partners in innovation as a factor of low importance. On the other hand, collaboration is crucial for the innovation process and public financing supporting this cooperation is significant in the Czech manufacturing (Prokop Stejskal - Kuba, 2019). Enterprises in the Czech Republic's machinery industry that cooperate with universities and public research centers demonstrate a greater positive influence on their overall performance (Stejskal et al., 2016).

Cooperation with public institutions such as universities is an issue which is extensively covered by many authors. According to Prokop, Stejskalová, and Hudec (2019), CEE economies have a low ability to cooperate with industry, public institutions and knowledge institutions. Standard Western innovation performance approaches are not applicable. Cooperation with government agencies is very low among Slovak manufacturing companies (Lesáková et al., 2018). However, Matulová et al. (2018) state that OI helps to build trust in the regional public administration. This is the case of the Open Innovation Session, a platform created by the regional government of the South Moravian region in Czechia which was set up with the aim of knowledge transfer facilitation. Another possible cooperation partners are schools and universities. 9.2\% of family businesses surveyed by Urbaníková et al. (2020) in Slovakia plan to cooperate with secondary schools, and $22.5 \%$ of companies plan to cooperate with universities. However, $74.5 \%$ of companies do not plan to cooperate with schools. On the other hand, universities represent important collaborative partners in the Czech Republic's machinery industry (Stejskal et al., 2016). From another point of view, Slovak universities are not exceptionally stimulated to cooperate with the business sector because of public funds being more stable and easier to obtain (Klasová et al., 2019).

\section{METHODOLOGY}

The aim of the paper is to analyze and systematize existing body of literature concerning the concept of Open Innovation in the Visegrád Four countries. The review was conducted using the principles outlined by Tranfield et al. (2003). Papers and articles published between 2013 and 2021 were considered for the purpose of this paper. The time span was chosen in order to focus on the up-to-date information because Open Innovation is a very dynamic research area. Thus, the first ten years after the initial work on Open Innovation by Chesbrough (2003) were not taken into account.

The keywords which were used to search for relevant studies were "Open Innovation" along with various combinations of terms "Visegrad", "Visegrad Four", "Czechia" (or "Czech Republic"), "Hungary", "Poland" and "Slovakia". The studies had to focus on at least one of the Visegrád Four countries in their results (those which have only mentioned any of the countries were not chosen for the final sample). Studies which mentioned "Open Innovation" only in the literature review with no subsequent follow-up on the topic in the results were also excluded. Google Scholar was used as a database.

No type of research output was excluded. The body of literature which was examined includes articles in scientific journals, books, book chapters, and conference proceedings. The sample was then filtered to contain only research really focusing on the Open Innovation or any of its aspects (predominantly cooperation) in at least one of the Visegrád Four countries. 
Finally, 36 studies fulfilling the criteria were considered for the literature review itself. Among them, 20 were single-country studies, 2 studies focusing on several or all V4 states but not other countries and 14 studies in which some or all Visegrád countries were part of the larger sample.

The studies were subsequently compared in order to find their common topics, with cooperation as the most mentioned of all (13 cases out of 36). Nevertheless, one research can also deal with several topics at once. Special emphasis was put on the research focusing solely on V4, as these studies have a larger potential to describe the specific features of these countries than the larger-sample research.

More detailed approach to literature review - e.g., article by Teixeira (2014) on National Systems of Innovation which combined main trends, scientific roots and influence of the literature - might be used also for the Open Innovation concept. However, this complex approach is more suitable for a larger and more in-depth works which are not strictly limited by the length of the paper.

\section{RESULTS AND DISCUSSION}

The literature review has shown two main findings. There are 11 sub-topics of Open Innovation examined in various studies, with cooperation/collaboration being the leading research area. This is in line with the definition of the Open Innovation by Chesbrough (2003) that places internal and external ideas and paths to market on the same level. The sub-topics are specified later in this part of the paper.

The second main result is that even though there are quite many single-country studies of the Open Innovation in the V4 states, there are only a few which are focused on the intra-group comparison. This is an important issue because it is rather difficult to establish differences or similiarities of the Open Innovation approach among all of the V4 countries.

The research on Open Innovation in the V4 countries can be divided into two groups. The first one contains studies in which the Visegrád Four are only a part of the larger research sample (larger-sample studies). As the findings of these papers are usually generalised and not specific for each of the countries in the sample, they have only a limited informative value in depiction of Open Innovation in the V4. The second group of research is focused exclusively on the V4. They are either single-country studies or papers dealing with at least two of the V4 states. However, the rarest are studies which investigate all four countries of the group. Among the single-country studies, Czechia is represented by 5 research papers, Hungary by 3, and Poland and Slovakia are the focus of 6 studies each.

6 of the larger-sample studies have used the secondary data from the Community Innovation Survey (CIS). However, this data does not include information on Polish enterprises throughout different editions. 11 studies have focused specifically on the SMEs. Open innovation might be suitable to overcome their often limited resources and thus the focus on this group is justified. Sectoral approach was used only for the wine industry ( 2 papers of the same authors) and for the manufacturing (4 studies).

There are several groups of authors who are doing research on Open Innovation in one or several V4 countries, e. g., Lisowska - Stanisławski, Prokop - Stejskal or Greco - Grimaldi Cricelli. Due to the rapidly changing environment, the continuity if the research is important to get the up-to-date results.

11 sub-topics were identified within the concept of OI in the studies reviewed: cooperation/collaboration (13 studies), involvement with public institutions (6), public funding (5), size of the companies engaged in OI (5), sectoral approach (4), culture of the companies 
(5), radical innovation (3), eco-innovation (3), information sources (2), intellectual property (2) and drivers of OI (2).

Overview of the papers focused only on one or several V4 states (mainly single country studies) is presented in table 1.

Tab. 1 Open Innovation single-country studies/studies focusing solely on the V4 countries

\begin{tabular}{|c|c|c|}
\hline Authors & $\begin{array}{l}\text { Countries } \\
\text { involved } \\
\text { among V4 }\end{array}$ & Main findings \\
\hline $\begin{array}{l}\text { Bobenič Hintošová } \\
\text { - Bruothová, } 2019\end{array}$ & SK & $\begin{array}{l}\text { Innovation performance expressed as gross expenditure on } \\
\text { research and development is negatively influenced by FDI inflows, } \\
\text { especially in the case of greenfield investment. }\end{array}$ \\
\hline $\begin{array}{l}\text { Dries et al., 2013; } \\
2014\end{array}$ & $\mathrm{HU}$ & $\begin{array}{l}\text { OI in the Hungarian wine sector occurred in the idea generation } \\
\text { phase in } 63 \% \text { of the surveyed companies. in the development } \\
\text { and commercialisation phases the share of OI decreased to } 55 \% \\
\text { and } 43 \% \text {, respectively. OI is influenced by regional and also } \\
\text { company-specific factors. Larger and younger companies are } \\
\text { more likely to engage in OI. }\end{array}$ \\
\hline $\begin{array}{l}\text { Chandler - } \\
\text { Krajcsák, } 2021\end{array}$ & $\mathrm{HU}$ & $\begin{array}{l}\text { Based on the sample of } 1056 \text { university students in Hungary, } \\
\text { there are four components supporting intrapreneurial behaviour: } \\
\text { Planning on results, Bearing the burden, Innovating for others } \\
\text { and Learning from mistakes. }\end{array}$ \\
\hline Dvouletý, 2019 & $\mathrm{CZ}$ & $\begin{array}{l}\text { Based on the secondary data during } 2005-2017 \text {, self-employed } \\
\text { workers accounted for } 12 \% \text { of economically active population in } \\
\text { Czechia whereas job creators represented only } 3.2 \% \text {.The overall } \\
\text { engagement in entrepreneurship and self-employment was } \\
\text { higher }(15.2 \%) \text { than the EU average }(13 \%) \text {. }\end{array}$ \\
\hline $\begin{array}{l}\text { Dziurski - Sopińska, } \\
2020\end{array}$ & PL & $\begin{array}{l}\text { OI approach is present in high-tech but also non-high-tech } \\
\text { industries as well. The most important drivers are market-driven } \\
\text { whereas the barriers are legal and financial issues. }\end{array}$ \\
\hline Klasová et al., 2019 & SK & $\begin{array}{l}\text { Slovak universities are not exceptionally stimulated to cooperate } \\
\text { with the business sector because of public funds being more } \\
\text { stable and easier to obtain. }\end{array}$ \\
\hline $\begin{array}{l}\text { Kmecová - Vokoun, } \\
2020\end{array}$ & $\mathrm{CZ}$ & $\begin{array}{l}\text { Cooperation increases the innovation activity of SMEs. They are } \\
\text { also more active in terms of R\&D expenditures per one } \\
\text { employee. }\end{array}$ \\
\hline Knošková, 2015 & SK & $\begin{array}{l}\text { Radical innovators are open to explore new ideas in the external } \\
\text { environment and these companies build external and internal } \\
\text { networks and link their innovation projects to company strategy. } \\
\text { Their entrepreneurial culture is focused on the flexibility, } \\
\text { experimenting and creating space for radical innovations. }\end{array}$ \\
\hline $\begin{array}{l}\text { Lesáková et al., } \\
2018\end{array}$ & SK & $\begin{array}{l}\text { Slovak SMEs in the sector "Manufacture of machinery and } \\
\text { equipment not elsewhere classified" ( } 68.62 \% \text { of enterprises in } \\
\text { the sample) consider cooperation with external partners in } \\
\text { innovation as a factor of low importance. The main partners for } \\
\text { cooperation are customers and suppliers. Cooperation with } \\
\text { government agencies is very low. }\end{array}$ \\
\hline $\begin{array}{l}\text { Lisowska - } \\
\text { Stanisławski, } 2015\end{array}$ & PL & $\begin{array}{l}\text { Cooperation of Polish SMEs with business environment } \\
\text { institutions in the context of OI is at a low level. }\end{array}$ \\
\hline
\end{tabular}




\begin{tabular}{|c|c|c|}
\hline Authors & $\begin{array}{c}\text { Countries } \\
\text { involved } \\
\text { among V4 }\end{array}$ & Main findings \\
\hline $\begin{array}{l}\text { Matulová et al., } \\
2018\end{array}$ & $\mathrm{CZ}$ & $\begin{array}{l}\text { OI support in the form of Open Innovation Session platform for } \\
\text { knowledge transfer helps to create new partnerships, reduces } \\
\text { transaction costs and builds trust in the regional public } \\
\text { administration. }\end{array}$ \\
\hline $\begin{array}{l}\text { Mazur - Zaborek, } \\
2016\end{array}$ & PL & $\begin{array}{l}\text { Innovative culture had positive effect on the scope of OI } \\
\text { sources, the relation between innovative culture and percentage } \\
\text { of sales from new and modified products as a metric of } \\
\text { innovativeness was not proven. }\end{array}$ \\
\hline Mielcarek, 2015 & PL & $\begin{array}{l}\text { The OI concept has resulted in a creation of joint venture and a } \\
\text { new business model. }\end{array}$ \\
\hline $\begin{array}{l}\text { Odei - Stejskal - } \\
\text { Prokop, } 2020\end{array}$ & $\begin{array}{l}\mathrm{CZ}, \mathrm{HU} \\
\mathrm{PL}, \mathrm{SK}\end{array}$ & $\begin{array}{l}\text { Microenterprises are the least innovative of all the company } \\
\text { sizes. Larger firms are product and process innovators. }\end{array}$ \\
\hline Prokop et al., 2017 & $\begin{array}{l}\mathrm{CZ}, \mathrm{HU}, \\
\mathrm{SK}\end{array}$ & $\begin{array}{l}\text { The investment to internal research and development affects } \\
\text { revenues from innovated products in the Czech Republic and } \\
\text { Hungary but not in Slovakia. Investment in external research } \\
\text { and development affects this type of turnover only in Hungary. } \\
\text { Similarly, public financing had a positive impact on revenues } \\
\text { from innovated products only in Hungary but not in the Czech } \\
\text { Republic and Slovakia. }\end{array}$ \\
\hline $\begin{array}{l}\text { Prokop - Stejskal - } \\
\text { Kuba, } 2019\end{array}$ & $\mathrm{CZ}$ & $\begin{array}{l}\text { Collaboration is crucial for the innovation process and public } \\
\text { financing supporting this cooperation is significant in the Czech } \\
\text { manufacturing. Cooperation among companies has led to } \\
\text { technical innovation activity and increase in revenues. }\end{array}$ \\
\hline $\begin{array}{l}\text { Stanisławski - } \\
\text { Lisowska, } 2015\end{array}$ & PL & $\begin{array}{l}\text { Innovation of Polish SMEs is relatively low. There are two main } \\
\text { causes of this situation: the low potential of the enterprises } \\
\text { (their limited resources) and relatively low innovation openness } \\
\text { (OI, measured by the tendency for cooperation with the } \\
\text { environment - other companies, business or research } \\
\text { institutions). The aim of SMEs is, therefore, to seek greater } \\
\text { openness to the environment in order to acquire new } \\
\text { knowledge. Operation of closed enterprises seems to be } \\
\text { impossible in the long run. }\end{array}$ \\
\hline Stanisławski, 2020 & PL & $\begin{array}{l}\text { Among the Polish SMEs, market is the main external } \\
\text { determinant influencing the use of OI. As for the internal } \\
\text { determinants, willingness to improve internal innovativeness and } \\
\text { to attract new customers are the most important. }\end{array}$ \\
\hline Stejskal et al., 2016 & $\mathrm{CZ}$ & $\begin{array}{l}\text { Enterprises in the Czech Republic's machinery industry that } \\
\text { cooperate with universities and public research centers } \\
\text { demonstrate a greater positive influence on their overall } \\
\text { performance. Universities represent important collaborative } \\
\text { partners in the Czech Republic's machinery industry. These } \\
\text { collaborations between enterprises and universities positively } \\
\text { affect enterprises' creation of innovation - both product and } \\
\text { process. Inefficient provision of public aid in the machinery }\end{array}$ \\
\hline
\end{tabular}




\begin{tabular}{|l|l|l|}
\hline \multicolumn{1}{|c|}{ Authors } & $\begin{array}{l}\text { Countries } \\
\text { involved } \\
\text { among V4 }\end{array}$ & \multicolumn{1}{c|}{ Main findings } \\
\hline & & $\begin{array}{l}\text { industry in the Czech Republic is possibly caused by excessively } \\
\text { granting public funding without directly monitoring its impact. }\end{array}$ \\
\hline $\begin{array}{l}\text { Urbaníková et al., } \\
2020\end{array}$ & SK & $\begin{array}{l}21.3 \% \text { of the surveyed family companies in Slovakia cooperated } \\
\text { with other companies or institutions on the development of } \\
\text { innovations. 9.2\% of family businesses plan to cooperate with } \\
\text { secondary schools, and 22.5\% of companies plan to cooperate } \\
\text { with universities. Surprisingly, 74.5\% of companies do not plan } \\
\text { to cooperate with schools. }\end{array}$ \\
\hline Zajko, 2017 & SK & $\begin{array}{l}\text { Research and Innovation Strategy for Smart Specialization } \\
\text { (RIS3) in Slovakia for 2014 - 2020 does not deal with OI } \\
\text { concept. Awareness of OI among Slovak companies is not high, } \\
\text { especially in the case of SMEs. }\end{array}$ \\
\hline
\end{tabular}

Source: own elaboration based on the findings of the authors cited

The overlapping of the research topics is not very significant. Among the similar findings, larger companies seem to be more willing to engage in OI (Dries et al., 2013; 2014 and Odei et al., 2020). Cooperation of Polish and Slovak SMEs with entities as government agencies and business environment institutions is at a low level (Lesáková et al., 2018; Lisowska Stanisławski, 2015). Market drivers including attraction of new customers are the most important for the Polish companies according to two diffferent studies by Stanisławski (2020) and Dziurski and Sopińska (2020).

There are also some notable differences among the countries. Different types of financing can have very different outcomes in each country as can be seen in the work by Prokop et al. (2017). Hungary has embedded OI in its innovation strategies which is not the case of Slovakia (Zajko, 2017). Innovation performance was negatively influenced by FDI in the case of Slovakia (Bobenič Hintošová - Bruothová, 2019). Czech companies in the manufacturing sector that cooperate with universities display positive influence on their performance (Stejskal et al., 2016). On the other hand, only $22.5 \%$ of family companies in Slovakia surveyed by Urbaníková et al. (2020) plan to cooperate with universities. This opinion seems to be mutual as the willingness of Slovak universities to cooperate with businesses is not high because public funds are more stable and easier to obtain (Klasová et al., 2019). The public funding for Czech manufacturing companies is not efficient according to Stejskal et al. (2016) due to its large size and absence of direct monitoring.

\section{CONCLUSION}

This paper is probably the first attempt to summarize the body of literature on the Open Innovation in the Visegrád countries. Its findings might be used in further research on this topic or in other literature reviews which might focus either on different sub-topics of the Open Innovation or they might examine solely one of the V4 countries.

The research gap seems to be in the comparison of all V4 countries in the field of Open Innovation. Visegrád states are often included in the larger research samples in studies on Open Innovation. This makes it more difficult to outline any specific conclusions for these countries. The single country studies are focused on many different aspects, such as cooperation, funding or culture. Due to their large variety of sub-topics, it is rather difficult to draw a common conclusion on Open Innovation in these countries in general. However, there 
are some notable inter-country differences, e.g., in the effectiveness of different sources of finance or cooperation with public institutions.

It would be also interesting to compare how the countries have used the the EU funds in the $2014-2020$ programming period in terms of innovative projects. The same can be said about the Recovery and Resilience Plans which should be heavily focused on the innovation and green economy. The use of sectoral approach might be interesting to compare e.g., the companies with domestic and foreign owners in the same country or SMEs and large companies in the same sector.

Limitations of the research and methodology include the dynamism of the research field and the relatively small number of the single-country studies or studies focusing solely on the V4 states. Open innovation and innovation in general are very dynamic research topics. The results of the studies are not necessarily valid for long periods of time and they need to be repeated often because of the rapidly changing environment. OI research should be therefore regularly repeated even on the issues which were already examined in detail. The singlecountry studies and studies focused solely on the V4 countries are important because their findings allow for the comparison with other states and identification of their potential differences in terms of Open Innovation.

Further research might be focused on the comparison of different sub-topics mentioned in the results and discussion part of the paper across all Visegrád countries. Another possibility is to examine the Open Innovation across several sub-topics in a single-country study. The case study approach is also undertilized even though it might bring important and useful information about the specific companies and their approaches to open inovation.

\section{REFERENCES}

Alassaf, D., Dabić, M., Shifrer, D., \& Daim, T. (2020). The impact of open-border organization culture and employees' knowledge, attitudes, and rewards with regards to open innovation: an empirical study. Journal of Knowledge Management, 24 (9), 2273-2297. https://doi.org/10.1108/JKM-02-2020-0122

Battisti, G., Gallego, J., Rubalcaba, L., \& Windrum, P. (2015) Open innovation in services: knowledge sources, intellectual property rights and internationalization. Economics of $\begin{array}{llll}\text { Innovation and New 223-247. } & \text { 24(3), }\end{array}$ https://doi.org/10.1080/10438599.2014.924745

Bobenič Hintošová, A. \& Bruothová, M. (2019). A LINK BETWEEN INNOVATION PERFORMANCE AND INWARD FOREIGN DIRECT INVESTMENTS: A CASE OF SLOVAKIA. In IISES 49th International Academic Conference, Dubrovnik (pp. 36 - 47). Dubrovnik; International Institute of Social and Economic Sciences. Retrieved 27 December 2020, from https://www.iises.net/proceedings/iises-international-academic-conference-dubrovnik/tableof-content?cid $=98 \&$ iid $=006 \&$ rid $=12114$

Chandler, N. \& Krajcsák, Z. (2021). Intrapreneurial Fit and Misfit: Enterprising Behavior, Preferred Organizational and Open Innovation Culture. Journal of Open Innovation: Technology, Market, and Complexity, 71), 61. http://dx.doi.org/10.3390/joitmc7010061

Chesbrough, H. W. (2003). Open Innovation: The New Imperative for Creating and Profiting from Technology. Boston, MA: Harvard Business School Press.

Civelek F., Kulkarni, R., Fritz, K-P., Meyer, T.,Troulost, C., Guenther, T., \& Zimmetmann, A. (2020). Open-Eco-Innovation for SMEs with Pan-European Key Enabling Technology Centres. Clean Technologies, 2(4), 422-439. https://doi.org/10.3390/cleantechnol2040026 
Cricelli, L., Grco, M., \& Grimaldi, M. (2016). ASSESSING THE OPEN INNOVATION TRENDS BY MEANS OF THE EUROSTAT COMMUNITY INNOVATION SURVEY. International Journal of Innovation Management, 30(3). https://doi.org/10.1142/S1363919616500390

Damioli, G., Ghisetti, C., Vertesy, D., \& Vezzulli, A. (2021). Open for growth? Evidence on EU countries and sectors. Economics of Innovation and New Technology, 30(2), 197-219. https://doi.org/10.1080/10438599.2019.1688459

Dodourova, M. \& Bevis, K. (2014). Networking innovation in the European car industry: Does the Open Innovation model fit?. Transportation Research Part A: Policy and Practice, 69, 252 - 271. https://doi.org/10.1016/j.tra.2014.08.021

Dries, L., Pascucci, S., Török, Á., \& Tóth, J. (2013). Open Innovation: A Case-study of the Hungarian Wine Sector. EuroChoices, 12(1), 53 - 59. Retrieved 14 February, 2021 from https://www.researchgate.net/publication/236694401_Open_Innovation_A_Casestudy_of_the_Hungarian_Wine_Sector

Dries, L., Pascucci, S., Török, Á., \& Tóth, J. (2014). Keeping Your Secrets Public? Open Versus Closed Innovation Processes in the Hungarian Wine Sector. International Food and Agribusiness Management Review, 171), 147 - 162. Retrieved 29 December 2020, from https://www.researchgate.net/publication/283416853_Keeping_Your_Secrets_Public_Open_ Versus_Closed_Innovation_Processes_in_the_Hungarian_Wine_Sector

Dvouletý, O. (2019). Development of Entrepreneurial Activity in the Czech Republic over the Years 2005-2017. Journal of Open Innovation: Technology, Market, and Complexity, 5(3), 38. http://dx.doi.org/10.3390/joitmc5030038

Dziurski, P. \& Sopińska, A. (2020). Does industry matter? Drivers and barriers for open innovation in high-tech and non-high-tech industries-Evidence from Poland, International Journal of Management and Economics, 56(4), 307-323. https://doi.org/10.2478/ijme-20200024

Greco, M., Grimaldi, M., \& Cricelli, L. (2016). An analysis of the open innovation effect on firm performance. European Management Journal, 34(5), 501-516. https://doi.org/10.1016/j.emj.2016.02.008.

Greco, M., Grimaldi, M., \& Cricelli, L. (2017). Hitting the nail on the head: Exploring the relationship between public subsidies and open innovation efficiency. Technological Forecasting and Social Change, 118, 213-225. https://doi.org/10.1016/j.techfore.2017.02.022

Gyamfi, S. \& Stejskal, J. (2020). Cooperating for knowledge and innovation performance: the case of selected Central and Eastern European countries. Problems and Perspectives in Management, 18(4), 264-274. http://dx.doi.org/10.21511/ppm.18(4).2020.22

Klasová, S., Korobaničová, I., \& Hudec, O. (2019). University-Industry Links in Slovakia: What are the Factors Underlying the Number of Interactions with Industry?. Quality Innovation Prosperity, 23(1), 102-118. https://doi.org/10.12776/qip.v23i1.1137

Kmecová, I. \& Vokoun, M. (2019). Innovation activities of Czech businesses differences between urban and rural businesses. In J. Horák, J. Vrbka and Z. Rowland. SHS Web of Conferences - Volume 73; Innovative Economic Symposium 2019 - Potential of Eurasian Economic Union (IES2019). Les Ulis: EDP Sciences

Knošková, L'. (2015). Innovation Processes and Entrepreneurial Culture for Radical Innovations. The AMFITEATRU ECONOMIC journal, 17(38), 342-342. Retrieved 27 December 2020, from https://ideas.repec.org/a/aes/amfeco/v38y2015i17p342.html

Leitão, J., Pereira, D., \& Brito, S. de. (2020). Inbound and Outbound Practices of Open Innovation and Eco-Innovation: Contrasting Bioeconomy and Non-Bioeconomy Firms. Journal 
of Open Innovation: Technology, Market, and Complexity, 6(4), 145. http://dx.doi.org/10.3390/joitmc6040145

Lesáková, L'., Král', P., \& Gundová, P. (2018). Sme's partners in innovation cooperation: an empirical analysis of Slovak sme's. Zeszyty Naukowe Wyższej Szkoły Humanitas Zarządzanie, 19(4). 21-39. https://doi.org/10.5604/01.3001.0013.1632.

Lisowska, R. \& Stanisławski, R. (2015). The Cooperation of Small and Medium-sized Enterprises with Business Institutions in the Context of Open Innovation. Procedia Economics and Finance, 23, 1273 - 1278. https://doi.org/10.1016/S2212-5671(15)00509-2

Matulova, P., Maresova, P., Tareq, M. A. \& Kuča, K. (2018). Open Innovation Session as a Tool Supporting Innovativeness in Strategies for High-Tech Companies in the Czech Republic. Economies, 6(4), 69. http://dx.doi.org/10.3390/economies6040069

Mazur, J. \& Zaborek, P. (2016). Organizational Culture and Open Innovation Performance in Small and Medium-sized Enterprises (SMEs) in Poland. International Journal of Management and Economics, 51, 104 - 137. https://doi.org/10.1515/ijme-2016-0022

Mielcarek, P. (2015). Developing of innovation process in open innovation model - an IT case study. Przegląd Organizacji, 6, 33 - 41. Retrieved 30 December 2020, from https://przegladorganizacji.pl/plik/5f9ff75b4a734/PO_2020.06.pdf

Odei, S.A., Stejskal, J., \& Prokop, V. (2020). Revisiting the Factors Driving Firms' Innovation Performances: the Case of Visegrad Countries. Journal of Knowledge Economy, 11. https://doi.org/10.1007/s13132-020-00669-7

Podmetina, D., Soderquist, K. E., Petraite, M., \& Teplov, R. (2018). Developing a competency model for open innovation: From the individual to the organisational level. Management Decision, 56(6), 1306 - 1335. https://doi.org/10.1108/MD-04-2017-0445

Pop, O.-M. et al. (2015). The Role of Open Innovation in Eastern European SMEs: The Case of Hungary and Romania. In XXVI ISPIM Conference - Shaping the Frontiers of Innovation

Management. ISPIM. Retrieved 30 December 2020, from https://www.researchgate.net/publication/281236915_The_Role_of_Open_Innovation_in_Ea stern_European_SMEs_The_Case_of_Hungary_and_Romania

Prokop, V., Stejskal, J., \& Hudec, O. (2019). Collaboration for innovation in small CEE countries. E+M Ekonomie a Management, 22(1), 130-144. https://doi.org/10.15240/tul/001/2019-1-009.

Prokop, V., Stejskal, J., \& Kuvíková, H. (2017). The Different Drivers of Innovation Activities in European Countries: A Comparative Study of Czech, Slovak, and Hungarian Manufacturing Firms. Ekonomický časopis, 65(1), 31 - 45. Retrieved 28 December 2020, from https://dk.upce.cz/bitstream/handle/10195/70305/Prokop_Stejskal_Kuvikova_EC.pdf?sequen $\mathrm{ce}=1$ \&isAllowed $=\mathrm{y}$

Prokop, V., Stejskal, J., \& Kuba, O. (2019). Revealing the importance of cooperative ties and R\&D support within Czech manufacturing industry. In $2^{\text {nd }}$ International Conference on Research in Business, Management and Finance. Paris; Diamond Scientific Publishing. Retrieved 27 December 2020, from http://www.dpublication.com/wpcontent/uploads/2019/11/BMF236.pdf

Stanisławski, R. (2020). Open Innovation as a Value Chain for Small and Medium-Sized Enterprises: Determinants of the Use of Open Innovation. Sustainability, 12(8), 3290. http://dx.doi.org/10.3390/su12083290

Stanisławski, R. \& Lisowska, R. (2015). The Relations between Innovation Openness (Open Innovation) and the Innovation Potential of SMEs. Procedia Economics and Finance, 23, 1521 - 1526. https://doi.org/10.1016/S2212-5671(15)00330-5 
Stejskal, J., Mikušová Meričková, B., \& Prokop, V. (2016). THE COOPERATION BETWEEN ENTERPRISES: SIGNIFICANT PART OF THE INNOVATION PROCESS - A CASE STUDY OF THE CZECH MACHINERY INDUSTRY. Ekonomika a management, 19(3), 110 - 122. https://doi.org/10.15240/tul/001/2016-3-008

Teixeira, A. A. C. (2014). Evolution, roots and influence of the literature on National Systems of Innovation: a bibliometric account. Cambridge Journal of Economics, 38(1), 181-214. https://doi.org/10.1093/CJE/BET022

Tranfield, D., Denyer, D., \& Smart, P. (2003). Towards a methodology for developing evidenceinformed management knowledge by means of systematic review. British Journal of Management, 14(3), 207-222. Retrieved 28 December, 2020 from https://www.academia.edu/22505199/Towards_a_Methodology_for_Developing_Evidence_I nformed_Management_Knowledge_by_Means_of_Systematic_Review

Urbaníková, M., Štubňová, M., Papcunová, V., \& Hudáková, J. (2020). Analysis of Innovation Activities of Slovak Small and Medium-Sized Family Businesses. Administrative Sciences, 10(4), 80. http://dx.doi.org/10.3390/admsci10040080

Zajko, M. (2017). RIS3 STRATEGY VERSUS NATIONAL OPEN INNOVATION STRATEGY IN SLOVAKIA. In ICRES 2017: International Conference on Research in Education and Science. ISRES Publishing. Retrieved 28 December 2020, from https://dergipark.org.tr/en/download/article-file/337864 